\title{
Avaliação biomecânica das fraturas intra-articulares do calcâneo e sua correlação clínica radiográfica
}

\author{
Biomechanical evaluation of intra articular calcaneal fracture and clinical radiographic correlation
}

Marcos Emillo Kuschnaroff Contreras ${ }^{1}$, Adriane Mara de Souza Muniz², Juliana Barcellos de Souza², Aluisio Otavio Vargas

Avila ${ }^{3}$, Noé Gomes Borges Junior ${ }^{4}$, Diogo Rath Fingerl Barbosa ${ }^{5}$, Luciano Manoel Martins Kroth ${ }^{6}$, Marcos dos Reis Filho

\section{RESUMO}

O presente estudo teve o objetivo de oferecer uma avaliação clínica, radiográfica e biomecânica de pacientes com fratura intraarticular de calcâneo, submetidos à redução aberta e fixação interna. A amostra consistiu em 22 pacientes, 20 do sexo masculino e dois do sexo feminino, com idade média de 40,95 ( $\pm 11,63)$ anos. Os autores realizaram avaliações radiográficas do ângulo de Böhler e Gissane, no pré e no pós-operatório, além de utilizarem a tomografia computadorizada para avaliação da classificação de Sanders.

A avaliação da Distribuição da Pressão Plantar foi realizada pelo sistema F-scan

Os resultados clínicos encontrados foram satisfatórios apresentando, pontuação média de 75,5 no critério da AOFAS.. A redução cirúrgica resultou em uma melhora dos ângulos de Böhler e Gissane. $\mathrm{O}$ estudo mostrou diferenças estatisticamente significantes entre o antepé o retropé fraturados no que tange sobre a área de contato, pressão e força de reação do solo. Os valores encontrados para estes parâmetros foram maiores no retropé que no antepé fraturados.

A trajetória de Pressão (COP) foi menor no pé fraturado que no pé normal. Encontrou-se correlação entre o Ângulo de Gissane após a redução e o Segundo Pico de Força, indicando que quanto melhor a redução deste ângulo, melhor a impulsão. Também encontrou-se a correlação entre a pontuação AOFAS e o Primeiro Pico de Força, mostrando que quanto melhor o resultado clínico melhor o apoio do retropé.

Descritores: Calcâneo; Biomecânica; Fraturas.

\section{SUMMARY}

The present study had an objective to perfom a clinical, radiographic and biomechanical evaluation in patients with calcaneal fractures submitted to open reduction with internal fixation. The sample consisted of 22 patients -20 male and 2 female with an average age of $40,95( \pm 11,63)$ years old. The authors have done radiographic evaluation of the pre and post operatory of Böchler and Gissane angles; furthermore, they used a CT scanning for Sander's classification of calcaneal fractures. The plantar pressure distribution was analyzed with F-scanning system. The results of the intra-articular calcaneal fractures were clinically satisfactory, showed average punctuation with 75,5 in AOFAS criterion. The surgical reduction in a better angle of Böchler and Gissane.

The study showed statistical differences between the forefoot and rearfoot concerning the the contact area, average preassure and strength in the injured foot. The figures found to this parameter were bigger in the rearfoot than the forefoot.

The trajectory of pressure (COP) was shorter in the fractured foot than in the normal foot. The correlation between the angle of Gissane after the reduction and the second peak of force was found, showing as better as the reduction of this angle, the better is the impulsion. It was also found the correlation between the punctuation between AOFAS and the first peak of force, showing as better is the clinical result the better is the foot supporter.

Key words: Calcaneal; Biomechanical; Fracture

Work performed at the Hospital Governador Celso Ramos-FlorianópolisSC and Biomechanical Department of The State University of Santa Catarina - SC.

1 - Doctor Head of the Foot and Ankle Group Orthopedics and Traumatology Service of Governador Celso Ramos (HGCR). Mastering of Biomechanical Department of the of the State University of Santa Catarina.

2 - Physiotherapist. Master of the Biochemical Department of State University of Santa Catarina.

3 - Chairman of the Biomechanical Department of University of Santa Catarina. Phd in Biomechenical at Valderbilt University - Nashiville Tennesse - USA

4 - Professor of the Biologics Science of CEFID - Santa Catarina University. PhD in Biophysics at Clermont 1 - Université dá AuvergneClermont - France.

5 - Resident of the Orthopedics and Traumatology Services of HGCR. 6 - Doctor of the Foot and Ankle of Orthopedics and Traumatology Services. HGCR

7 - Head of the of Orthopedics and Traumatology Service of Celso Ramos Hospital (1990-2001)

Address: Rua Professor Marcos Cardoso Filho 696 Florianópolis - SC Cep: 8837 -140 - e-mail: mekc@intergate.com.br
Endereço para correspondência: Rua Professor Marcos Cardoso Filho 696 - Florianópolis-SC - CEP 88037-040 - e-mail : mekc@intergate.com.br

Trabalho recebido em 18/10/03. Aprovado em 09/04/04. 


\section{INTRODUÇÃO}

O calcâneo é o osso mais comumente fraturado entre os ossos do tarso, contudo, ainda não há um consenso sobre o seu tipo ideal de tratamento(11,16,21). Historicamente, as fraturas de Calcâneo eram tratadas de maneira conservadora, entretanto, com os avanços tecnológicos, atualmente os tratamentos visam a redução cirúrgica e a fixação interna ${ }^{(11)}$.

Segundo Slatis et al. ${ }^{(25)}$ a fratura de Calcâneo compreende de 1 a $2 \%$ das fraturas no adulto. Esta fratura consiste em um trauma altamente incapacitante devido ao tempo prolongado de afastamento do trabalho, para o tratamento; e aos resultados no pós-tratamento. Além disto apresenta alta incidência em adultos e adultos-jovens, ou seja,

Lowery et al. ${ }^{(10)}$ realizaram uma extensa revisão bibliográfica com a história das fraturas do calcâneo. Desde os tempos remotos, a fratura do Calcâneo vem sendo um tema controverso na medicina. Em 1720, Garongeat descreveu as fraturas cominutivas do Calcâneo como fraturas por esmagamento denotando a total perda da anatomia que ocorre após esta fratura. O primeiro a descrever a anatomia da fratura do Calcâneo foi Malgaine, em $1843^{(10)}$

Desde Hipócrates o tratamento destas fraturas não passava de enfaixamento. Clark introduziu em 1850 a fixação com pinos. Em 1882, Charles Bell iniciou a redução cruenta de tais fraturas e, em 1902, Morestein adicionou a fixação interna. Em 1908, Cotton e Wilson descreveram as deformidades ocasionadas pela fratura do Calcâneo, e descreveram a redução incruenta ou redução cruenta limitada seguida de imobilização como tratamento(10).

O primeiro a propor uma classificação anatômica para as fraturas do Calcâneo foi Böhler em 1930, propondo como tratamento uma técnica de redução através de manipulação, compressão e tração associada à imobilização. Em 1951, Essex-Lopresti apresentou uma classificação baseada no mecanismo de trauma da fratura, classificação esta, que permanece em grande uso até os dias de hoje em locais onde não há acesso fácil à Tomografia Computadorizada (TC). Em 1989, Sanders propôs uma classificação através da TC e ressaltou a importância da fratura da faceta posterior como um índice prognóstico ${ }^{(10)}$. na população economicamente ativa.

\section{INTRODUCTION}

The calcaneal is more likely bone to be fractured between the tarsus bone; however there is not a common sense yet about the best type of treatment ${ }^{(11,16,21)}$. Historically, the calcaneals fractures were treated in a conventional way, however with technological advances, nowadays the treatments tend to decrease the quantity of surgeries and internal fixation ${ }^{(11)}$.

According to Slatis et $\mathrm{al}^{(25)}$ the calcaneal fractures is the most common fracture in adults. These fractures consist of work the high disability trauma due to the long time on leave of their jobs; and also the post operatory results.

Furthermore it shows high incidences in adults and young adults, that is, economic active population.

Lowery et $\mathrm{al}^{\left({ }^{(10)}\right.}$ were responsible for a wide bibliography review of the calcaneal fractures. Since the ancient times, the calcanel fracture has been a controversy issue in Medicine. In 1720, Garongeat described the shattered calcaneal fractures as compressing fractures denoting a complete loss of the anatomy after this fracture. In 1843 Malgaine was the first to describes the anatomical calcaneal fracture ${ }^{(10)}$.

Since Hipocrates the treatment of these fractures were with bands. In 1850 Clark released the fixation of pines. In 1882, Charles Bell started the reduction of these severe fractures, and in 1902, Morestein added the internal fixation. In 1908 Cotton and Wilson described the deformities caused by the calcaneal fractures, and also described the not so severe reduction or several limited reduction following by the treatment with plaster ${ }^{(10)}$.

1930, Bohler was the one to purpose an anatomical classification for the calcaneal fractures, suggesting as treatment a reduction technique with the manipulation, compression and traction associated with the immobilization. In 1951, Essex-Lopresti showed a classification based on fracture trauma mechanism, and this classification remains widely used so far in places where there is an easy approach to computerized tomography (CT). In 1989, Sanders purposed a classification with (CT) and emphasized the posterior surface fracture as a post-diagnoses $^{(10)}$

The purpose of this study consist in assessing the calcaneal

\begin{tabular}{|c|c|c|c|c|c|c|}
\hline $\begin{array}{l}\text { Idade } \\
\text { Age }\end{array}$ & $\begin{array}{c}\text { Sexo } \\
\text { Sex }\end{array}$ & $\begin{array}{l}\text { Ocupação } \\
\text { Occupation }\end{array}$ & $\begin{array}{l}\text { Mecanismo } \\
\text { Mechanism }\end{array}$ & $\begin{array}{l}\text { Lado } \\
\text { Side }\end{array}$ & $\begin{array}{c}\text { Complicações } \\
\text { Severity }\end{array}$ & $\begin{array}{l}\text { Lesões Associadas } \\
\text { Associated Injuries }\end{array}$ \\
\hline 42 & $\mathrm{M}$ & Aposentado / Retired & QA & $\mathrm{D}$ & $\mathrm{N}$ & Fratura L1 / Fracture L1 \\
\hline 47 & $\mathrm{M}$ & Pedreiro / Bricklayer & QA & $E$ & $\mathrm{~N}$ & Fratura tornozelo / Ankle fracture \\
\hline 58 & $\mathrm{~F}$ & Aposentado / Retired & QA & $\mathrm{D}$ & $\mathrm{N}$ & Fratura radio D / Radial D frecture \\
\hline 45 & $\mathrm{M}$ & Pedreiro / Bricklayer & QA & $\mathrm{D}$ & $\mathrm{N}$ & $\mathrm{N}$ \\
\hline 59 & $\mathrm{M}$ & Aposentado / Retired & $\mathrm{QA}$ & $\mathrm{D}$ & $\mathrm{N}$ & $\mathrm{N}$ \\
\hline 36 & $\mathrm{M}$ & Motorista / Driver & AC AUTO & $\mathrm{D}$ & sínd.compartimental / compartmental sind. & Fratura exposta / Exposure fracture \\
\hline 53 & $\mathrm{M}$ & Professor / Teacher & AC AUTO & $E$ & Perda da redução / Reduction loss & Fratura tíbia D / Tibial D fracture \\
\hline 55 & $\mathrm{M}$ & Zelador / Caretaker & QA & $\mathrm{D}$ & $\mathrm{N}$ & $\mathrm{N}$ \\
\hline 54 & $\mathrm{M}$ & Aposentado / Retired & QA & $\mathrm{D}$ & Osteomielite / Osteomyelitis & $\mathrm{N}$ \\
\hline 27 & $\mathrm{M}$ & Pintor / Painter & QA & $\mathrm{E}$ & $\mathrm{N}$ & $\mathrm{N}$ \\
\hline 34 & $\mathrm{M}$ & Industriário / Businessman & QA & $\overline{\mathrm{D}}$ & $\mathrm{N}$ & $\mathrm{N}$ \\
\hline 42 & $\mathrm{M}$ & & QA & $\mathrm{E}$ & $\mathrm{N}$ & $\mathrm{N}$ \\
\hline 30 & $\mathrm{M}$ & Motorista / Driver & AC AUTO & $\mathrm{D}$ & $\mathrm{N}$ & $\mathrm{N}$ \\
\hline \multirow[t]{2}{*}{27} & $\mathrm{M}$ & Eletricista/Eletrician & QA & $E$ & $\mathrm{~N}$ & Fratura calcâneo / Calcaneal extra-articular \\
\hline & & & & & & D extra-articular / $R$ fracture \\
\hline 34 & $\bar{M}$ & Operário / Blue Collar Worker & QA & $\mathrm{E}$ & $\mathrm{N}$ & $\mathrm{N}$ \\
\hline 24 & $\mathrm{M}$ & Vendedor / Salesman & QA & $\bar{D}$ & $\mathrm{~N}$ & $\mathrm{~N}$ \\
\hline 44 & $\mathrm{M}$ & Pintor / Painter & QA & $\mathrm{E}$ & Perda da redução / Reduction Loss & $\mathrm{N}$ \\
\hline 26 & $\mathrm{M}$ & Operário / Blue Collar Worker & QA & $\mathrm{D} / \mathrm{E}$ & Osteomielite E / L Osteomyelitis & Fratura de coluna / Column fracture \\
\hline 22 & $\mathrm{~F}$ & Cabeleleira / Hairdresser & QA & $\mathrm{D} / \mathrm{E}$ & Osteomielite E / L Osteomyelitis & Fratura de coluna / Column fracture \\
\hline 44 & $\mathrm{M}$ & Pedreiro / Bricklayer & QA & $E$ & $\mathrm{~N}$ & $\mathrm{~N}$ \\
\hline 47 & $\mathrm{M}$ & Pedreiro / Bricklayer & QA & $\bar{E}$ & $\mathrm{~N}$ & $\mathrm{~N}$ \\
\hline 42 & $\mathrm{M}$ & Aposentado / Retired & QA & $\mathrm{D}$ & Infecção superficial / Superficial infection & $\mathrm{N}$ \\
\hline
\end{tabular}

$\mathbf{M}=$ masculino, $\mathbf{F}=$ feminino, $\mathbf{Q A}=$ queda de altura, $\mathbf{A C}$ AUTO= acidente automobilístico, $\mathbf{D}=$ direito, $\mathbf{E}=$ esquerdo, $\mathbf{N}=$ não houve

$\boldsymbol{M}=$ male, $\boldsymbol{F}=$ female, $\mathbf{Q A}=$ fall from high, $\boldsymbol{A C} \mathbf{A U T O}=$ car accident, $\boldsymbol{D}=$ right, $\boldsymbol{E}=$ left, $\boldsymbol{N}=$ none

Tabela 1 - Características da amostra

Table 1 - Sample Characteristic 
O objetivo deste estudo consistiu em avaliar as fraturas de Calcâneo através de uma análise da distribuição da pressão plantar, de forma dinâmica durante a marcha e relacionar estes dados com avaliações clínica, radiográfica e tomográfica.

\section{MÉTODO}

Durante o período de janeiro de 1995 a janeiro de 2001, foram submetidos a tratamento cirúrgico de fraturas intra-articulares do calcâneo, 61 pacientes, no Hospital Governador Celso Ramos- Florianópolis-SC (HGCR). Compareceram para a avaliação da marcha no Laboratório de Biomecânica da Universidade do Estado de Santa Catarina, 22 pacientes, onde analisamos 24 pés fraturados, com tempo de seguimento mínimo de 15 meses (Tabela 1). A idade média foi de 40,95 anos $( \pm 11,63)$ variando entre 22 a 59 anos. Vinte pacientes eram do sexo masculino e dois do sexo feminino, sendo 11 casos com acometimento do lado direito e nove no lado esquerdo, e dois casos bilaterais. Todos os pacientes foram submetidos à redução aberta por via lateral, com uso de placas e parafusos, com parafusos e fios ou apenas por fios de Kirschner. Enxerto ósseo foi utilizado em apenas um caso. Quanto ao mecanismo do trauma 19 casos foram por queda de altura e três casos por acidente automobilístico.

A análise da distribuição da pressão plantar (DPP) foi realizada através do sistema F-Scan (TEKSCAN, Inc, Bostom, MA), que é um sistema matricial de sensores de força e resistência. São colocadas palmilhas sensorizadas dentro do calçado dos pacientes, e estas ligadas a uma unidade CPU de computador com o sistema de análise de dados instalado. Os pacientes são instruídos a deambular em sua cadência natural. A freqüência de aquisição foi de $120 \mathrm{~Hz}$ e o tempo de coleta de $6 \mathrm{~s}$

Para a análise da DPP os plantigramas foram divididos em antepé e retropé, sendo aplicado o teste t-student para amostras dependentes $(p<0,05)$ em antepé e retropé do mesmo lado. Estes dados foram correlacionados com resultados obtidos nas avaliações clínica, radiográficas e tomográficas.

\begin{tabular}{|c|c|c|c|c|c|c|}
\hline $\begin{array}{l}\text { Classificação de } \\
\text { Essex-Lopresti }\end{array}$ & $\begin{array}{c}\text { Classificação } \\
\text { de Sanders }\end{array}$ & $\begin{array}{l}\text { Böhler } \\
\text { pré }\end{array}$ & $\begin{array}{l}\text { Böhler } \\
\text { pós }\end{array}$ & $\begin{array}{c}\text { Gissane } \\
\text { pré }\end{array}$ & $\begin{array}{l}\text { Gissane } \\
\text { pós }\end{array}$ & AOFAS \\
\hline $\begin{array}{l}\text { Essex-Lopresti } \\
\text { classification }\end{array}$ & $\begin{array}{c}\text { Sanders } \\
\text { classification }\end{array}$ & $\begin{array}{c}\text { Böhler } \\
\text { pré }\end{array}$ & $\begin{array}{c}\text { Böhler } \\
\text { pós }\end{array}$ & $\begin{array}{l}\text { Gissane } \\
\text { pré }\end{array}$ & $\begin{array}{c}\text { Gissane } \\
\text { post }\end{array}$ & AOFAS \\
\hline Depressão articular & II B & $2^{\circ}$ & $19^{\circ}$ & $108^{\circ}$ & $112^{\circ}$ & 82 \\
\hline Língua & IIB & $-3^{\circ}$ & $9^{\circ}$ & $104^{\circ}$ & $112^{\circ}$ & 97 \\
\hline Depressão articular & $\pi \mathrm{B}$ & $12^{\circ}$ & $12^{\circ}$ & $97^{\circ}$ & $98^{\circ}$ & 56 \\
\hline Língua & II B & $15^{\circ}$ & $29^{\circ}$ & $137^{\circ}$ & $129^{\circ}$ & 87 \\
\hline Depressão articular & II B & $18^{\circ}$ & $37^{\circ}$ & $127^{\circ}$ & $113^{\circ}$ & 67 \\
\hline Depressão articular & III AC & $30^{\circ}$ & $28^{\circ}$ & $130^{\circ}$ & $139^{\circ}$ & 70 \\
\hline Língua & $\mathrm{N}$ & $-9^{\circ}$ & $12^{\circ}$ & $119^{\circ}$ & $100^{\circ}$ & 50 \\
\hline Depressão articular & $\mathrm{N}$ & $20^{\circ}$ & $24^{\circ}$ & $110^{\circ}$ & $126^{\circ}$ & 67 \\
\hline Língua & $\pi \mathrm{B}$ & $20^{\circ}$ & $15^{\circ}$ & $80^{\circ}$ & $120^{\circ}$ & 80 \\
\hline Língua & III AC & $-14^{\circ}$ & $21^{\circ}$ & $122^{\circ}$ & $112^{\circ}$ & 78 \\
\hline Depressão articular & III AC & $5^{\circ}$ & $\mathrm{N}$ & $114^{\circ}$ & $\mathrm{N}$ & 90 \\
\hline Depressão articular & III AC & $24^{\circ}$ & $32^{\circ}$ & $147^{\circ}$ & $130^{\circ}$ & 80 \\
\hline Depressão articular & II A & $\mathrm{N}$ & $24^{\circ}$ & $\mathrm{N}$ & $136^{\circ}$ & 85 \\
\hline Língua & IV & $-25^{\circ}$ & $17^{\circ}$ & $115^{\circ}$ & $130^{\circ}$ & 82 \\
\hline Depressão articular & II B & $44^{\circ}$ & $39^{\circ}$ & $89^{\circ}$ & $104^{\circ}$ & 77 \\
\hline Depressão articular & IV & $14^{\circ}$ & $33^{\circ}$ & $76^{\circ}$ & $107^{\circ}$ & 98 \\
\hline Depressão articular & $\mathrm{N}$ & $-4^{\circ}$ & $20^{\circ}$ & $144^{\circ}$ & $115^{\circ}$ & 75 \\
\hline Depressão articular & TV & $-6^{\circ}$ & $35^{\circ}$ & $102^{\circ}$ & $135^{\circ}$ & 60 \\
\hline Depressão articular & IV & $3^{\circ}$ & $18^{\circ}$ & $102^{\circ}$ & $118^{\circ}$ & 81 \\
\hline Depressão articular & IV & $-5^{\circ}$ & $32^{\circ}$ & $95^{\circ}$ & $133^{\circ}$ & 53 \\
\hline Depressão articular & IV & $0^{\circ}$ & $31^{\circ}$ & $90^{\circ}$ & $130^{\circ}$ & 81 \\
\hline Língua & IIIAC & $0^{0}$ & $26^{\circ}$ & $96^{\circ}$ & $113^{\circ}$ & 87 \\
\hline Depressão articular & IIA & $25^{\circ}$ & $32^{\circ}$ & $120^{\circ}$ & $126^{\circ}$ & 74 \\
\hline Depressão articular & III AC & $-7^{0}$ & $16^{\circ}$ & $102^{0}$ & $106^{\circ}$ & 55 \\
\hline
\end{tabular}

Fonte/Source: HGCR-SC

Depressão Articular $=$ Joint Depression Type Língua $=$ Tongue Type $\mathbf{N}=$ sem Tomografia Computadorizada (TC) $\mathbf{N}=$ without CT-scan

Tabela 2 - Classificação das fraturas da amostra Table 2- Fracture Classification

\begin{tabular}{|l|c|c|}
\hline $\begin{array}{l}\text { Classificação } \\
\text { de Sanders } \\
\begin{array}{l}\text { Sanders } \\
\text { classification }\end{array}\end{array}$ & Casos & Porcentagem \\
\hline & & Percentage \\
\hline IIA & 2 & $8 \%$ \\
\hline II B & 7 & $29 \%$ \\
\hline III AC & 6 & $25 \%$ \\
\hline IV & 6 & $25 \%$ \\
\hline Sem TC/NO CT & 3 & $13 \%$ \\
\hline Total & 24 & $100 \%$ \\
\hline \multicolumn{3}{|l}{} \\
\hline \multicolumn{2}{|l|}{ Fonte/Source: HGCR-SC } \\
\hline
\end{tabular}

Tabela 3 - Classificação tomográfica Table 3 - Tomographic classification

\begin{tabular}{|l|c|c|}
\hline $\begin{array}{l}\text { Classificação de } \\
\text { Essex-Lopresti }\end{array}$ & Casos & Porcentagem \\
\hline $\begin{array}{l}\text { Essex-Lopresti } \\
\text { classification }\end{array}$ & Cases & Percentage \\
\hline Depressão Articular/Ajoint depression case & 17 & $71 \%$ \\
\hline Língua / Tongue Type & 7 & $29 \%$ \\
\hline Total & 24 & $100 \%$ \\
\hline Fonte/Source: HGCR-SC & & \\
\hline
\end{tabular}

Tabela 4 - Classificação radiográfica

Table 4 - Radiographic classification fractures with analyses of plantar pression distribution, in a dynamic way during the bait and relate these clinical diagnoses data, radiographic and tomographic.

\section{METHOD}

Within January, 1995 to January of 2001,61 patients were submitted to intra articular calcaneal surgical treatment, in Governador Celso Ramos Hospital - Florianópolis-SC (GCRH). 22 patients made part of the of the bait evaluation test at the Biomechanical Laboratory of Santa Catarina University where 24 fractured feet, with at least 15 months followed up (Table 1). The average age was of 40,95 years old $( \pm 11,63)$ ranging from 22 to 59 years old. Twenty patients were male and two female, being 11 cases with the right side access and 9 at the left side, and two cases were bilateral. All the patients were submitted to open reduction by lateral approach, using screw and plate, with only screw and thread or only with Kirschner threads. A transplant of bone was used only in one case. About the trauma mechanism of 19 cases were because of falls from high and three cases for car accidents.

The plantar pressure distribution (PPD) investigation was done with the F-Scan system (TEKSCAN, Inc, Boston, $M A)$, which is a matritial sensor system of resistence and strength. Sensore sole are put is the patients'shoes and these are connected to a CPU unity of a computer with an installed data analyzes system. The patients are advised to stroll in their natural cadence. The acquisition frequency of $120 \mathrm{~Hz}$, time of collection of $6 \mathrm{~s}$ ) 
Os pacientes foram avaliados clinicamente pelo critério da American Organization of Foot and Ankel Society (AOFAS) para o retropé, sendo esta, sempre realizada pelo mesmo avaliador. Realizou-se avaliação tomográfica pela classificação de Sanders e radiográfica por Essex-Lopresti. Através de radiografias na incidência de perfil foram medidos os ângulos de Böhler e Gissane.

\section{RESULTADOS}

A Tabela 2 mostra um resumo das avaliações radiográficas, tomográfica e clínica.

Através de radiografias na incidência de perfil foram medidos os ângulos de Böhler e Gissane. A média do ângulo de Böhler, no préoperatório foi de $6,9^{\circ}$, sendo seus parâmetros de normalidade entre $25^{\circ}$ e $40^{\circ(11)}$. No pós-operatório, após a redução cirúrgica, o ângulo médio encontrado foi de $24^{\circ}$, havendo, portanto diferença significativa no pré e pós-operatório $\quad(t=-5,70, p<0,001)$.

O ângulo de Gissane no pré-operatório apresentou valor médio de $109,8^{\circ}$, sendo de $119,3^{\circ}$ no pós-operatório. Foi considerado valor normal deste ângulo de $140^{\circ}$, havendo diferença significativa nas médias dos ângulos no pré e pós-operatório $(t=-2,10, p<0,05)$. (Tabela 5)

O critério clínico da AOFAS para o retropé, apresentou pontuação média de 75,5 pontos.

O sistema utilizado baseia-se em uma escala de 100 pontos, e avalia dor (40 pontos) , função (50 pontos) e alinhamento (10 pontos).

A avaliação da Classificação Tomográfica de Sanders mostra um discreto predomínio do tipo II sobre o tipo III e IV , como mostra a tabela 3.
In order to investigate the PPD the plantar diagram which was divided into forefoot and rearfoot, the $\mathrm{t}$-test was given to independent samples ( $p$ 0,05 ) at the forefoot and rearfoot same side This data were compared to the results obtained in clinical, radiographs and tomography evaluation.

The patients were clinically evaluated by the American organization of foot and ankle society (AOFAS) criterion for the rearfoot, being done by the same instructor. The tomography analyses were made based on Sanders and the radiography by Essex-Lopresti. With the radiography in the profile incidence was measured with theangles of Böhler and Gissane.

\section{RESULTS}

The Table 2 shows a radiographic, tomographic and clinical summary of the sample.

With the radiographies the profile incidence were measured using the angles of Böhler and Gissane. The average of the angle of Böhler in the pre-operatory was $6,9^{\circ}$, and the parameters under normality between $25^{\circ}$ and $40^{\circ}$ (22). at the post-operation, after surgical reduction, the average angle found was $24^{\circ}$, therefore with an important difference in the pre and post operatory $(t=5,70, p<0,001)$

The angle of Gissane in the pre-operatory showed an average figure of $109,8^{\circ}$, and $119,3^{\circ}$ in the post operatory. It was considered as a normal figure this angle of $140^{\circ}$, with an important difference in the average of the pre and post-operatory angles $(t=-2,10, p<0,05)$. (Table 5)

The clinical discretion with AOFAS for the rearfoot, presented

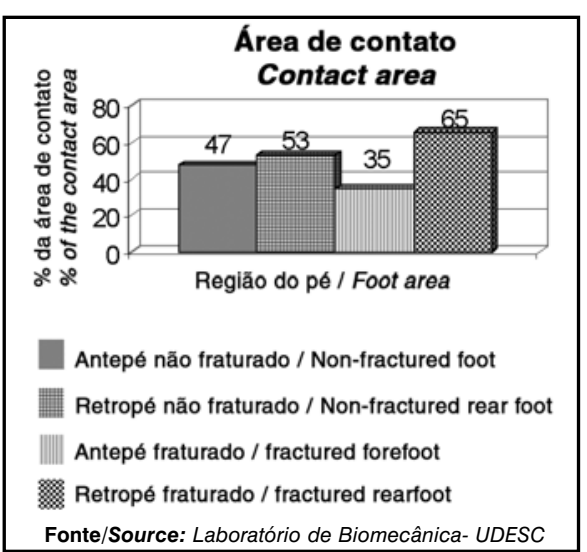

Gráfico 1- Área de Contato dos pés, indicando a porcentagem de área de contato do retropé e antepé durante a fase de apoio da marcha.

Graph 1 - Foot contact area, indicating the percentage of rearfoot and forefoot contact area during the stance phase of the gait.

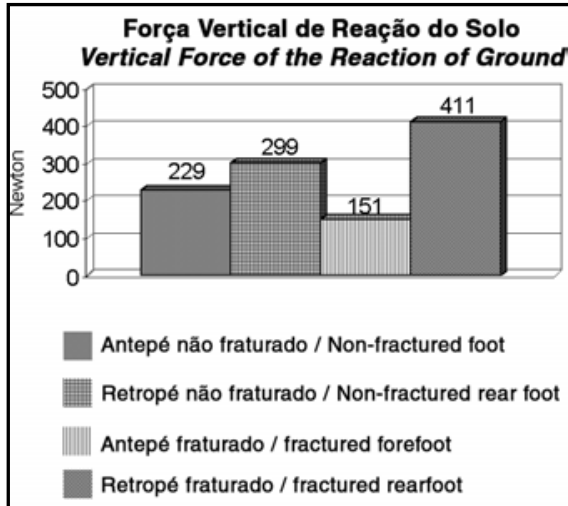

Fonte/Source: Laboratório de Biomecânica- UDESC

Gráfico 2 - Força Vertical de Reação do Solo sob os pés, indicando em Newton (valor absoluto) a força sob cada pé durante a fase de apoio da marcha.

Graph 2 - Vertical Force, in Newton (absolute value), indicating the force under each foot during the stance phase of the gait.

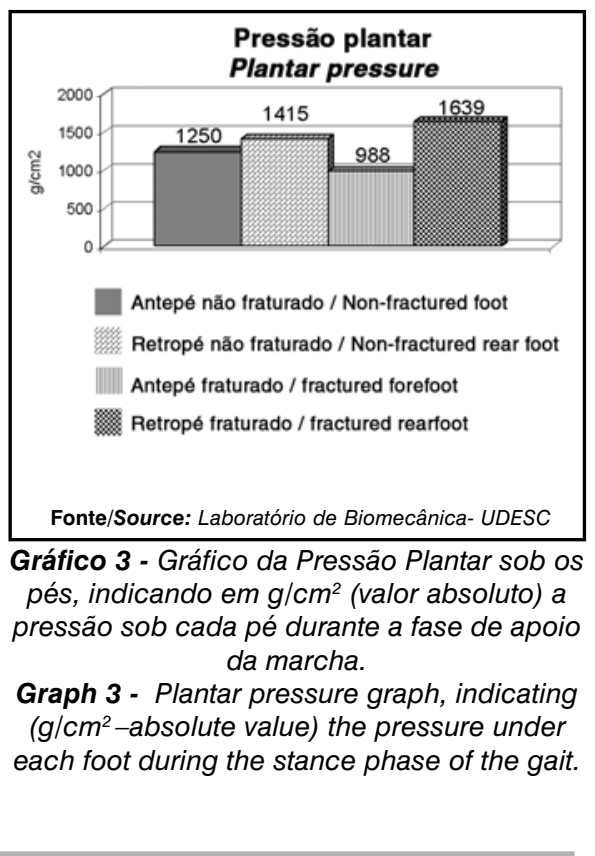

ACTA ORTOP BRAS 12(2) - ABR/JUN, 2004 
Quanto à classificação radiológica de Essex-Lopresti, 17 fraturas eram do tipo Depressão Articular e sete do tipo Língua (Tabela 4).

Os resultados adquiridos através do sistema F-Scan estão apresentados nos Gráficos de 1 a 3 , ilustrando os resultados da Área de Contato, da Força e da Pressão Média no antepé e retropé de ambos lados.
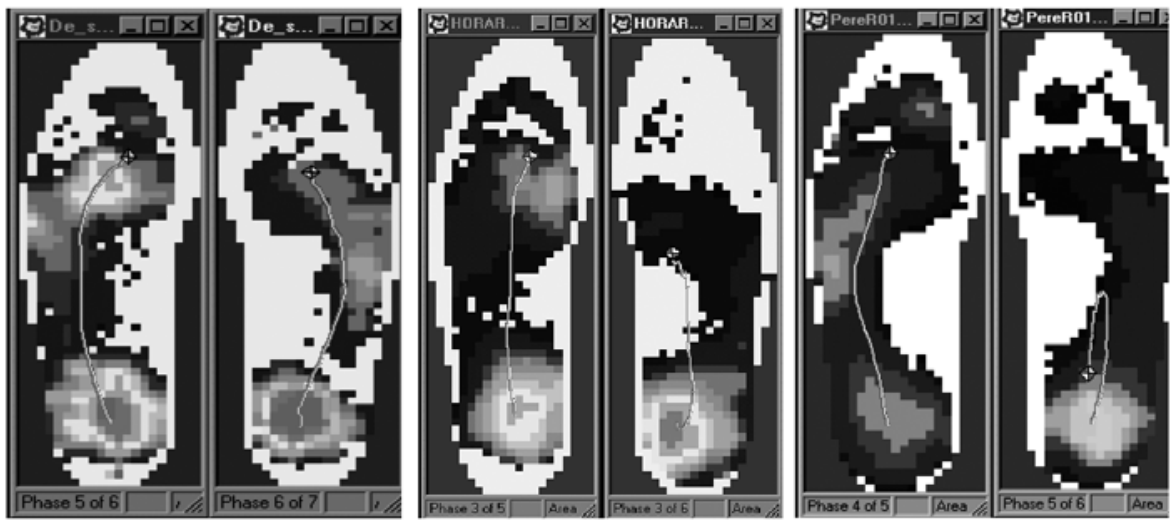

Figura 1 - Trajetória do centro de pressão

Figure 1- Trajectory of the Pressure Center

average punctuation of 75.5 points.

The system to make use of the 100 points scale and value pain (40 points), function (50 points) and alinement (10 points).

The Sander's tomographic classification evaluation shows a smooth dominance of type II than the type II and IV, as shown in the Table 3.

About the Essex-

Ao analisarmos a distribuição da pressão plantar dos pacientes submetidos à redução cirúrgica da fratura de Calcâneo unilateral, verificamos que os valores médios da Área de contato do antepé e retropé do mesmo lado apresentam uma diferença significativa entre o antepé e o retropé do lado fraturado $(\mathrm{t}=-3,95, \mathrm{p}<0,001)$ evidenciando a maior área no retropé fraturado.(Tabela 6) (Gráfico 1)

Este fato deve-se ao déficit na transferência do peso para o antepé durante a marcha. Não havendo diferença significativa para os valores médios da variável no lado não fraturado.

Ao analisar a Força exercida no pé fraturado, houve diferenças significativas entre as médias de Força do antepé e do retropé no lado da fratura ( $t=-5,65 ; p=0,00004)$, sem diferença significativa no lado contralateral. A diminuição na Força da região do antepé (Segundo Pico de Força), representa redução na força de impulsão durante a marcha.(Tabela 6) (Gráfico 2).

A Pressão média no pé fraturado apresentou diferença significativa entre 0 antepé e o retropé $(t=4,93$, $p=0,0002$ ), não havendo diferença significativa no membro contralateral para esta variável. Existe uma pressão maior sob o retropé fraturado significativa em relação à pressão neste antepé. (Tabela 6) (Gráfico 3).

Aqueles que sofreram fraturas bilaterais, não apresentaram diferença significativa entre os valores médios de Área de contato, Pressão e Força entre o antepé e retropé.

A análise do Centro de Pressão (COP), mostra que no pé fraturado, a trajetória foi menor. O COP apresentou três diferentes comportamentos: deslocamento até a região entre a segunda e primeira cabeça dos metatarsos $(61 \%$ dos casos), deslocamento até o mediopé
Lopresti's radiological classification, 17 fractures were joint depression type and seven of tongue type (Table4).

The results obtained by the F-scan system are shown in the graph 1 to 3 , illustrating the results of the contact area, the strength and average pressure in the both sides of the forefoot and rear foot.

When analyzing the plantar pressure distribution of the patients submitted to the unilateralis calcaneal fracturesurgery, we observed the average figures of the contact at the side had important difference between the fractured side of the forefoot and rearfoot $(\mathrm{t}=-3,95$ $\mathrm{p}<0,001$ ) confirming the larger rearfoot fracture area.(Table 6) (Graph 1)

This fact is due to the deficit in the weight transference to the forefoot during gait with no important difference to the average figures at the nonfracture side.

While analyzing the pressure force on the fractured foot, there were important averages of force of the forefoot and rearfoot fractured side $(\mathrm{t}=$ Ta 6 - Teste t-Student entre as variáveis Biomecânicas da Marcha analisadas
Table 6 - Test between the evaluated biomechanics variables of the gait $5,65 ; p=0,00004)$, but no difference of the counter-lateral side. The de-

\section{Trajetória do COP} The COP trajectory

Deslocamento até a região da segunda e primeira cabeca dos metatarsos Displacement between the second and first head of metatarsus

Deslocamento até o mediopé Displacement till the medium foot

Deslocamento do COP não saindo do retropé Porcentagem Percentage Displacement of the COP not coming from the rear foot

Fonte/Source: Laboratório de Biomecânica- UDESC

Tabela 7 - Trajetórias do COP

Table 7 - Trajectory of the Pressure Center area (under the peak of force), shows reduction in the strength expulsion during the gait(Table 6) (Graph 2).

The average pressure in the fractured foot showed important difference between the forefoot and rear foot $(t=4,93, p=0,0002)$, with no important difference in the counter lateralis to this variant. There is an important higher pressure under the fractured rearfoot in relation of the one on the forefoot (Table 6) (Graph 3).

Those who had bilateralis 
(27\%) e deslocamento do COP não saindo do retropé (11\%).

As diferentes trajetórias do Centro de Pressão (COP) encontradas estão representadas na Figura 1, e a distribuição da amostra na Tabela 7.

O Ângulo de Gissane após a redução cirúrgica da fratura apresentou correlação com o Segundo Pico de Força (SPF) dos pés fraturados $(r=$ $0,61 ; p<0,05)$. Não houve correlação do Ângulo de Gissane com o Primeiro Pico de Força (PPF), Área e Pressão de retropé e antepé fraturado. (Gráfico 4)

O Critério Clínico AOFAS apresentou correlação significativa com o Primeiro Pico de Força (PPF) $(r=0,60$; $p<0,05)$. Não encontramos correlação dos valores do Critério Clinico da AOFAS com o SPF, com a relação do SPF/PPF, Área e Pressão em retropé fraturado. (Gráfico 5).

\section{DISCUSSÃO}

Em relação à idade, sexo, e mecanismo de trauma, a nossa casuística se compara à da literatura ${ }^{(1,9,13,18-}$ 20,22,26,27). Quanto ao lado fraturado, chama atenção que houve apenas dois casos de fratura intra-articular bilateral, enquanto nas séries publicadas $^{(1,9,13,15,18,19,22,27)}$ há, geralmente, maior número de casos de fraturas bilaterais.

A via de acesso utilizada foi a abordagem lateral, escolhida por grande parte dos autores $(1,2,9,13,20,22,23)$ apesar de haver autores que utilizam a abordagem medial ${ }^{(9)} \mathrm{e}$ a abordagem lateral e medial ${ }^{(8,10,15)}$. Em nosso meio, Fernandes ${ }^{(5)}$, descreveu a utilização da via anterior, sobre o seio do tarso, e suas vantagens pelo menor tamanho da incisão, o menor risco de necrose de pele e a não agressão aos tendões peroneiros ${ }^{(5)}$

O uso de enxerto, aplicado em apenas um dos casos, é uma outra controvérsia, sendo indicado por alguns ${ }^{(1,2,9,13,19)}$ e proscrito por ou$\operatorname{tros}^{(18,20,22,23,27)}$. Acreditamos que o uso de enxerto autólogo não aumenta a estabilidade da síntese, não melhora o resultado final e aumenta o risco de infecção, além da presença de uma segunda ferida cirúrgica.

A quantidade de lesões associadas nos casos descritos (36 \%) e suas localizações (fraturas dos membros inferiores e vértebras) se comparam com grande parte da literatura, que apresenta percentuais que variam de $27 \%$ a $61,2 \%(9,13,18,19,22)$.

As complicações encontradas na amostra do presente estudo também estiveram de acordo com a literatura. A osteomielite e a perda de redução por nós observadas são complicações encontradas freqüentemente na literatura ${ }^{(1,2,6,9,18,22,26)}$, bem como a síndrome compartimental ${ }^{(14,17)}$. Vários autores destacam também as complicações relacionadas à ferida operatória ${ }^{(1,2,9,13,15,18,22,26,27)}$.

Quanto a avaliação clínica pelo critério da AOFAS, nossa amostra apresentou valor médio de $75.5( \pm 13.35)$ pontos, valor este próximo ao encontrado por Infante et al. ${ }^{(6)}$, de 78 pontos. Segundo este autor fractures, did not show important difference between the average figures of the contact area and between the forefoot and rearfoot

The Pressure Center Observations (COP), show in the fractured foot, the trajectory was shorter. The COP showed three different behaviors: displacement between the second and first head of the metatarsus $(61 \%$ of the cases), displacement until the medien foot foot (27\%) and COP displacement not coming from the rearfoot (11\%).

The different trajectories of the (COP) Pressure Center found are showed in Figure 1, and the sample distribution in Table 7

The angle of Gissane after the reduction fracture surgery had correlation with the second peak of force (SPF) from the fractured foot $(r=0,61 ; p<0,05)$, area and pressure of the rearfoot and forefoot fractured.

The angle of Gissane after the reduction fracture surgery Vs SPF in the fractured foot (Graph 4).

The Clinical Criterion AOFAS showed important correlation with the First Peak of Force (FPF) $(0,60$; $\mathrm{p}<0,05)$.

We did not find the clinical criterion value of the AOFAS with the SPF, with the relation of SPF/PPF, Area and Pressure in fractured foot (Graph 5).

\section{DISCUSSION}

Concern the age, sex, mechanism of trauma, our cause is compared to the one in the literature ${ }^{(1,9,13,18,20,22,26,27)}$. About the fractured side, it is drawn to only two cases of bilateralis intraarticular fracture, however in the set of publications ${ }^{(1,9,13,15,18,19,22,27)}$ there is usually higher number of bilateralis fractures.

The approach via used was the lateral one, chosen by most of the authors ${ }^{(1,2,9,13,20,22,23)}$, despite some authors using the medialis $^{(9)}$, and the laterallis and medialis approaches ${ }^{(8,10,15)}$, In 1997 Fernandes $^{(5)}$, one of us, described the use of the anterior approach, on the shaft of the tarsus, and its advantages due to smaller incision, having less risk of necroses of the skin and no severity with the peroneal tendons ${ }^{(5)}$

The use of transplant, made in only one of the cases, is another controversy, being prescribed by some physicians $^{(1,2,9,13,19)}$ and not by others ${ }^{(18,20,22,23,27)}$ It is believable the authologue transplants does not increase the syntheses stability, it does not improve the final results but increase the hospital infection, and a surgical injury.

The quantity of injuries associated with the described cases (36\%) and their location (the lower limbs and vertebras fractures) are compared with big part of the literature, which shows percentage ranging from $27 \%$ to $61,2 \%(9,13,18,19,22)$

The complications found in the sample of this study were also in accordance with the Literature. Osteomyelitis and the 
este índice demonstra que houve bons resultados funcionais, possibilitando ao paciente retornar as suas atividades. Nossa amostra apresenta valores do critério AOFAS, semelhante também aos encontrados por Sanders et al.(23), Zwipp et al.(27), Bezes et al.(2), Melcher et al. ${ }^{(13)}$, e em nosso meio Pimenta e Kojima ${ }^{(19)}$ e Moraes Filho et al. ${ }^{(15)}$.

A avaliação das Tomografias Axiais Computadorizadas através da classificação de Sanders também teve sua distribuição comparável às séries de Sanders et al. ${ }^{(23)}$ e Moraes Filho et al. ${ }^{(15)}$, com as fraturas tipo II predominando sobre as tipo III, que por sua vez predominaram sobre as tipo IV.

A avaliação das radiografias pré-operatórias através da classificação de Essex-Lopresti teve sua distribuição comparável com a literatura $^{(9,13,15,19)}$ demonstrando um predomínio do tipo em Depressão Articular sobre o tipo em Língua.

O Ângulo de Gissane após a redução cirúrgica da fratura apresentou correlação com o Segundo Pico de Força dos pés fraturados. Com o aumento do Ângulo de Gissane, aproximando-se do normal houve um aumento significativo na variável do Segundo Pico de Força, indicando maior impulsão com o antepé, sem correlação com o Primeiro Pico de Força, Área e Pressão de retropé e antepé fraturado.

O Critério Clínico AOFAS apresentou correlação significativa com o Primeiro Pico de Força (PPF). Quanto maior a pontuação no critério AOFAS maior apresentou-se o PPF, sem haver correlação com o Segundo Pico de Força, nem tampouco com a relação do SPF/PPF, Área e Pressão em retropé fraturado. Fernandes ${ }^{(5)}$ estudou 33 pacientes e 38 fraturas intra-articulares de calcâneo, II e III de Sanders, com seguimento mínimo de 24 meses, encontrou relação entre o ângulo de Böhler e o critério AOFAS(5).

Ao analisarmos a marcha e a distribuição da pressão plantar verificamos que os pacientes apresentaram a Área de Contato reduzida no antepé do lado fraturado. Assim como uma redução significativa dos valores de Pico de Força e Pressão Média nesta região. Este fato é um indicativo do déficit da transferência de peso para a região anterior do pé. Nos pés fraturados verificamos sobrecarga dos retropés, provavelmente em conseqüência da limitação do movimento da articulação subtalar e tibio-társica com fraqueza do tríceps sural, levando a um déficit na impulsão.

O critério de avaliação clínica utilizado, AOFAS, apresentou correlação significativa com os valores do Primeiro Pico de Força (PPF), indicando que os pacientes com melhores condições clínicas apresentavam índices maiores de PPF. A marcha patológica freqüentemente apresenta assimetria da força, redução de picos e redução de intervalos das curvas de força de reação do solo, sendo que o comportamento anômalo da força vertical pode ser um indicativo de descontrole muscular no paciente.

A análise do Centro de Pressão (COP), mostrou que no pé fraturado, a trajetória foi menor. O COP apresentou 3 diferentes comportamentos: deslocamento até a região entre a segunda e primeira cabeça dos metatarsos, deslocamento até o mediopé e deslocamento do COP não saindo do retropé. A trajetória normal do Centro de Pressão desloca-se até o hálux $x^{(3,12)}$. Os pacientes com fratura de calcâneo não apresentaram deslocamento normal do COP, diminuindo assim, as forças de impulsão durante a marcha, com redução da Área de Contato na região do antepé e aumento da Pressão e Força na região do retropé. Porém, verificamos que esses pacientes apresentaram aumento de parâmetros da marcha, como a Pressão e Força na região da fratura, o que se deve à perda de mobilidade funcional do complexo tornozelo-pé no pós-operatório.

Novas perspectivas na avaliação e tratamento das fraturas de calcâneo mostram que não basta o paciente voltar a caminhar, mas o padrão a ser adquirido é um fator relevante para a qualidade de vida do paciente. loss of reduction observed are frequently found in the literature $^{(1,2,6,9,18,22,26)}$ such as the compartimentation ${ }^{(14,17)}$ syndrome. Several authors appoint to the complications related to surgical injuries ${ }^{(1,2,9,13,15,18,22,26,27)}$

Concern the clinical evaluation under the AOFAS criterion of, our sample showed average value of $75.5( \pm 13.35)$ points, value approximately found for Infant et $\mathrm{al}^{(6)}$ of 78 points. According to this author this index shows there were good functional results, make it possible the patient come back to their activities. Our sample shows AOFAS value criterion, also similar to the ones found for Sanders et al.(23), Zwipp et al. (27), Bezes et al. ${ }^{(2)}$, Melcher et al. ${ }^{(13)}$, and among us Pimenta and Kojima ${ }^{(19)}$ and Moraes Filho et al. ${ }^{(15)}$.

The Axial computerized Tomography evaluation under Sanders classification also had its distributions compared to the set of Sanders et al.(23), and Moraes Filho et al. ${ }^{(15)}$, with the dominance of the fracture type II on type three, which had dominance on type IV.

The pre-operatory radiography evaluation under the Essex -Lopresti classification had his distribution compared to the one in the literature ${ }^{(9,13,15,19)}$ showing the joint depression type on the tongue type.

The angle of Gissane after the surgical fracture reduction showed correlation with the Second Peak of Force of the fractured feet. According with the increasing of the angle of Gissane, close to the normal one, there was an important increase in the variance of the Second Peak of Force, indicating higher impulsion with the forefoot, with no correlation with the First Peak of Force area and pressure of the rearfoot and forefoot fractures.

The clinical criterion AOFAS shoed important correlation with the first peak of force (FPF). As higher is the figure in the AOFAS criterion, the FPF was higher too, with no relation with the Second Peak of Force, neither relation with the (SPF/FPF), Area and Pressure of the fractured rearfoot. Fernandes ${ }^{(5)}$, studied 33 patients and 38 intra-articular calcaneal fractures, II and III by Sanders, with at least 24 months followed up, he found correlation with the angle of Böhler and AOFAS criterion ${ }^{(5)}$.

While analyzing the gait and the plantar pressure distribution we observed the patients showed the contact area reduced in the forefoot fractured side. As well as important values of the Peak of Force and the average Pressure in this area. This datum proves the deficit transference of weight to the anterior area of the foot. We observed in the fractured feet overload of rearfeet, probably because of the limited movement of the sub-tallar and tibial-tarsus articulation showing weakness of the sural triceps, leading to a deficit in the impulsion.

The clinical criteron evaluation used, AOFAS, showed important correlation with the values of the First Peak of Force (FPF), indicating the patients with better clinical conditions showed higher indexes in the FPF. The pathological gait often shows asymmetry of force, reduction of intervals in the curves of force in relation of the ground, considering the anomalous behavior of the vertical force, which can be an expressive muscular uncontrolled of the patient.

The Pressure Center analyses (COP) showed that the fractured foot, the trajectory was shorter. The COP presented three different behaviors: displacement until the area of the first and second head of the metatarsal, displacement till the median foot and displacement of COP not coming from the rearfoot. The normal trajectory of the Pressure Center till hallux ${ }^{(3,12)}$. The patients with calcaneals fracture did not show the normal COP displacement, decreasing then, the forces of impulsion during the gait, with the reduction of the Area of Contact in the forefoot region and increase of the Pressure of Force in the rearfoot re- 


\section{CONCLUSÃO}

Clinicamente o resultado cirúrgico das fraturas intra-articulares do Calcâneo foi satisfatório, alcançando média de 75,5 pontos, no critério AOFAS. A redução cirúrgica das fraturas do Calcâneo foi satisfatória na reconstrução do Ângulo de Böhler e do Ângulo de Gissane. Através dos plantigramas de Pressão, verificou-se diferença significativa entre as variáveis: Área de Contato, Pressão Média e a Força sendo maior no retropé que no antepé do lado do Calcâneo fraturado. gion. It is important to emphasize it was expected the patient, with the reflex protection minimized the loads on the injury surface. However, we observed these patients showed an increasing of the gait parameters, as the Pressure of Force on the fracture, is due to the loss of functional mobility of the complexity of the ankle-foot in the post-operatory.

New perspectives of evaluation and the calcaneals fracture treatment showed it is not enough that the patient comes back to walk, but the pattern to be obtained is a relevant factor to the quality of life of this patient.

\section{CONCLUSION}

Clinically the results of the surgical results of the intra-articular calcaneals fractures were satisfactory, reaching the average of 75.5 points, under the AOFAS criterion. The surgical reduction of calcaneal fractures were satisfactory in the reconstruction angle of Böhler and Gissane. With the plantygrams of Pressure, important difference was observed between the variability: The Contact Area, Average Pressure and the Force were higher in the rearfoot than in the forefoot of the fractured calcaneal side.

\section{REFERÊNCIAS BIBLIOGRÁFICAS}

1. Abidi NA, Dhawan S, Gruen GS, Vogt MT, Conti SF. Wound-healing risk factors after open reduction and internal fixation of calcaneal fractures. Foot Ankle Int 19:856-861, 1998.

2. Bezes H, Massart P, Delvaux D, Fourquet JP, Tazi F. The operative treatment of intraarticular calcaneal fractures: indications, technique, and results in 257 cases. Clin Orthop 290:55-59, 1993.

3. Cavanagh PR, Rodgers MM, Liboshi A. Pressure distribuition under symptonfree feet during barefoot standing. Foot Ankle Int 7:262-276, 1987.

4. Ebraheim NA, Elgafy H, Sabry FF, Tao S. Calcaneus fractures with subluxation of the posterior facet: a surgical indication. Clin Orthop 377:210-216, 2000.

5. Fernandes TD. Fraturas intra-articulares do calcâneo. Tratamento cirúrgico sem o uso de enxerto ósseo avaliação clínico-radiográfica. [Doutorado]. São Paulo: Faculdade de Medicina, Universidade de São Paulo, 1997.

6. Infante AF Jr. Heier KA, Lewis BO, Sanders RW. Open reduction internal fixation and immediate subtalar fusion for comminuted intra-articular calcaneal fractures: a review of 33 cases. J Orthop Trauma 14:142-143, 2000.

7. Kitaoka HB, Alexander IJ, Adelaar RS, Nunleu JA, Myerson MS, Sanders M. Clinical rating sistems for the ankle-hind foot, midfoot, hallux, and lesser toes. Foot Ankle Int 15:349-537, 1994

8. Kitaoka HB, Schaap EJ, Chao EYS, Kai-Nan A. displaced intra-articular fractures of the calcaneus treated non-operatively. Clinical results and analysis of motion and ground-reaction and temporal forces. J Bone Joint Surg Am 76:1531-1540, 1994

9. Kundel K, Funk E, Brutscher M, Bickel R. Calcaneal fractures: operative versus nonoperative treatment. J Trauma 41:839-845, 1996.

10. Lowery RBW, Calhoum JH. Fractures of the calcaneus. Part I: Anatomy, injury mechanism and classification. Foot Ankle Int 17:230-235, 1996.

11. Loucks C, Buckley R. Böhler's angle: correlation with outcome displaced intra-articular calcaneal fractures. J Orthop Trauma 13:554-558, 1999.

12. Manfio EF. Estudo de parâmetros antropométricos biomecânicos do pé humano para a fabricação de calçados segundo critérios de conforto, saúde e segurança. [Dissertação], Santa Maria: Universidade Federal de Santa Maria, 1995

13. Melcher G, Degonda F, Leutenegger A, Ruedi T. Ten-year follow-up after operative treatment for intra-articular fractures of the calcaneus. J Trauma 38:713716, 1995.
14. Mittlmeier T, Machler G, Lob G, Mtschler W, Bauer G, Vogl T. Compartment syndrome of the foot after intraarticular calcaneal fracture. Clin Orthop 269:241248, 1991

15. Moraes Filho DC, Provenzano E, Matos JR et al. Avaliação preliminar do tratamento cirúrgico de fraturas intra-articulares do calcâneo. Rev Bras Ortop 33:511-518, 1998

16. Mulcahy DM, McCormack DM, Stephens MM. Intra-articular calcaneal fractures: effect of open reduction and internal fixation on the contact characteristics of the subtalar joint. Foot Ankle Int 19:842-848, 1998.

17. Myerson M, Manoli A. Compartment syndromes of the foot after calcaneal fractures. Clin Orthop 290:142-150, 1993.

18. Pasqualerro WI, De Conti MC, Fonseca Filho FF, Santin RAL. Complicações e seqüelas de fraturas intra-articulares do calcâneo. Rev Bras Ortop 28:465 468, 1993.

19. Pimenta LSM, Kojima KE. Fraturas intra-articulares do calcâneo: resultados em longo prazo do tratamento cirúrgico. Rev Bras Ortop 28:469-473, 1993

20. Rockwood C, Green DP. Fraturas em adultos. 5. ed. Philadelphia, Saunders, 2001. p.1621-1690.

21. Sabry FF, Ebraheim NA, Mehalik JN, Rezcallah AT. Internal architecture of the calcaneus: implications for calcaneus fractures. Foot Ankle Int 21:114-118, 2000.

22. Salomão O, Fernandes TD, Carvalho Jr AE, Marques J, Imamura M. Fraturas do calcâneo: tratamento cirúrgico. Rev Bras Ortop 28:461-464, 1993.

23. Sanders R, Fortin P, Dipasquale T, Walling A. operative treatment in 120 displaced intraarticular calcaneal fractures: results using a prognostic computed tomography scan classification. Clin Orthop 290:87-95, 1993.

24. Schuh A, Hausel M. The difficulties in judgement of follow-up of open reducted and internal fixated-fractures of the os calcis. Does a practicable scoring system exist? J Orthop Trauma 14:452, 2000

25. Slatis K, Kiviluoto O, Santavirta S, Laasonen EM. Fractures of the calcaneum. J Trauma 19:939-943, 1979.

26. Tornetta P. The Essex-Lopresti reduction for calcaneal fractures revisited. Orthop Trauma 12:469-473, 1998

27. Zwipp $H$, Tscherne $H$, Thermann $H$, Weber T. Osteosynthesis of displaced intraarticular fractures of the calcaneus: results in 123 cases. Clin Orthop 290:76-86, 1993 